Available online at GSC Online Press Directory

GSC Biological and Pharmaceutical Sciences

e-ISSN: 2581-3250, CODEN (USA): GBPSC2

Journal homepage: https://www.gsconlinepress.com/journals/gscbps

(RESEARCH ARTICLE)

\title{
Synthesis and evaluation of some novel heterocyclic compounds containing an oxadiazole moiety
}

\author{
Bakshi Anjali 1 ${ }^{*}$, Kammari Sowmyasree ${ }^{1}$, Awasthi Archana ${ }^{1}$, Bhutada Shweta ${ }^{1}$, Pola Saritha ${ }^{2}$ and \\ Mantripragada Bhagvan Raju ${ }^{1}$ \\ ${ }^{1}$ Department of Pharmaceutical Analysis and Quality Assurance, Sri Venkateshwara College of Pharmacy, Osmania \\ University, Hyderabad -500081. \\ ${ }^{2}$ Pulla Reddy institute of pharmacy, Medak.
}

Publication history: Received on 25 December 2018; revised on 25 January 2019; accepted on 27 January 2019

Article DOI: https://doi.org/10.30574/gscbps.2019.6.2.0166

\begin{abstract}
Heterocyclic compounds analog have attracted wide attention due to their useful biological properties. Among them, 1,3,4-oxadiazoles have exhibited a wide range of biological properties including anti-bacterial, anti-viral, anti-fungal, anti-cancer, anti-tumor, anti-inflammatory, anti-hypertensive, anti-convulsant and anti-diabetic properties. The purpose of this study was to collect the literature work reported by researchers on oxadiazole derivatives for their various pharmacological activities and also efforts made on this moiety. This study covers the work reported on various biological activities of oxadiazole derivatives.
\end{abstract}

Keywords: Heterocyclic compounds; 1, 3, 4-oxadiazoles; Pharmacological activities

\section{Introduction}

Compounds containing heterocyclic ring systems are of great significance both medicinally and industrially. Oxadiazoles are the heterocyclic compounds comprehend one oxygen and two nitrogen atoms in a five membered ring [1,2] derived from furan by substitution of two methylene groups $(=\mathrm{CH})$ with two pyridine type nitrogen's (-N=). They possess a diversity of useful biological effects [3]. There are four known isomers of oxadiazole such as 1,2,3-0xadiazole, 1,2,4Oxadiazole, 1,3,4-Oxadiazole and 1,2,5-Oxadiazole [4] but the 1,2,3-Oxadiazole is quite unstable and revert in the form of diaziketone tautomer [5]. Oxadiazoles are frequently occurring motifs in drug like molecules, and they are often used with the intention of being bioisosteric replacements for ester and amide functionalities.Some of the recent review proclaimed that 1,3,4-oxadiazoles and its derivatives were reported to acquire antimicrobial [6], tuberculostatic [7], anti-inflammatory [8], antifungal [9], antibacterial [10] anticancer [11], analgesic [12] activities, anti-convulsant [13], anti-hepatitis B [14], antiparasitic [33]. Many drugs containing oxadiazole are in late clinical trials, including zibotentan (15) as an anticancer agent, ataluren (16) for the treatment of cystic fibrosis and raltegravir (17) an antiretroviral drug for the treatment of HIV infection. Some compounds having 1,3,4-oxadiazole unit are currently used as medicines: Fenadiazole is a hypnotic drug [18], MK-0633 p-toluenesulfonate is a 5-lypoxynase inhibitor [19], Nesapidil is an antihypertensive agent [20] and ABT-751-oxadiazole [21] and Furamizole are antibiotics [22, 23]. Several methods have been reported in the literature for the synthesis of 1,3,4-oxadiazoles. The most often used synthetic route for 1,3,4oxadiazoles includes reactions of acid hydrazides (or hydrazine) with acid chlorides/carboxylic acids and direct cyclization of diacylhydrazines using a variety of dehydrating agents such as phosphorous oxychloride [24], thionyl chloride [25], phosphorous pentaoxide [26], triflic anhydride [27], polyphosphoric acid [28], and direct reaction of acid with (N-isocyanimino-) triphenylphosphorane [29-32]. Various 2,5 substituted 1,3,4-oxadiazoles have been shown to be effective against a wide range of gram-positive and gram-negative bacteria [34-36].

\footnotetext{
${ }^{*}$ Corresponding author

E-mail address: anjalibakshi07@gmail.com
} 


\section{Material and methods}

\subsection{Material}

Reagent and solvents used were analytical grade and purchased from Merck. Analytical thin layer chromatography was carried out on TLC plates of $3 \times 15 \mathrm{~cm}$ coated with silica gel G for reaction monitoring and for determination of retardation factor. Spots of TLC were located by iodine chamber. Melting points of newly synthesized derivatives were determined on digital melting point apparatus (Flora; Perfit, India) and were found uncorrected. The IR spectra were recorded on FTIR-Shimadzu spectrometer using Nujol method. ${ }^{1} \mathrm{H}$ NMR and ${ }^{13} \mathrm{C}$ NMR spectra were recorded on BRUKER AVANCE II 400 NMR. Chemical shift values were expressed in $\delta$ ppm.

\subsection{Synthesis of substituted oxadiazolemannich bases}

\subsubsection{Synthesis of aryloxy acetic acid}

A solution of phenolic compounds 2-chlorophenol and 4-chlorophenol (10 g) in $\mathrm{NaOH}(33 \%, 35 \mathrm{ml})$, to this solution freshly prepared chloro acetic acid (50\%, $25 \mathrm{ml})$ was added and the sodium salt separated was dissolved by adding sufficient amount of water. The total mixture is taken in round bottom flask (RBF) and reflux for one hour. A clear solution obtained was cooled and acidified with $\mathrm{HCl}$.

\subsubsection{Synthesis of aryloxy acyl hydrazide}

Appropriate quantities of acid ( 0.1 mole) and ethanol $(50 \mathrm{ml})$ was introduced into a clean and dry RBF and stirred well for $10 \mathrm{~min}$. To the above mixture few drops of concentrated sulphuric acid were added and refluxed for 6 hrs. The reaction mixture was concentrated by distilling the excess ethanol under the reduced pressure and treated with saturated solution of sodium bicarbonate. The ester formed in the reaction was used for the preparation of hydrazides directly. The appropriate ester ( 0.1 mole) was dissolved in $50 \mathrm{ml}$ of ethanol in a clean and dry RBF and to this hydrazine hydrate $(0.1$ mole) was added. The reaction mixture was refluxed for period of $12 \mathrm{hrs}$. The excess ethanol was distilled off under reduced pressure. The resultant mixture was then poured into ice cold water and obtained solid was filtered and recrystallized from ethanol.

\subsubsection{Synthesis of substituted oxadiazole}

A mixture of aryloxy acyl hydrazide, potassium hydroxide (0.01 mole), ethanol (50 ml) and carbon disulphide (3 ml) was refluxed until the evolution of hydrogen sulphide ceased. The reaction mixture was concentrated, dissolved in water and acidified with $\mathrm{HCl}$. The precipitate was filtered and recrystallized from ethanol to give substituted oxadiazole.

\subsubsection{Synthesis of oxadiazolemannich bases}

A solution of substituted oxadiazole ( 0.001 mole) in absolute ethanol $(10 \mathrm{ml})$ was treated with formaldehyde $(0.5 \mathrm{ml})$. Later an amine was added with stirring and the reaction mixture was magnetic stirred for $2 \mathrm{hrs}$ in an ice bath. The precipitated mannich bases was collected and recrystallized from ethanol.

\subsection{Antibacterial and antifungal activity}

\subsubsection{Preparation of Nutrient agar media and Nutrient broth}

Nutrient agar medium (100 ml) was been prepared by adding agar ( $2 \mathrm{~g})$, beef extract (1 g), peptone(1 g), sodium chloride $(0.5 \mathrm{~g})$ in water with heating and the $\mathrm{pH}$ was adjusted to 7.0 - 7.5. To prepare Nutrient broth(100 ml) in water beef extract $(1 \mathrm{~g})$, peptone $(1 \mathrm{~g})$, sodium chloride $(0.5 \mathrm{~g})$ were dissolved with heating and the $\mathrm{pH}$ was adjusted to 7.0 7.5. The nutrient media and Nutrient broth were been autoclaved at $121^{\circ} \mathrm{C}$ at $15 \mathrm{lb}$ pressure for $15 \mathrm{~min}$ and used for sub-culturing of bacteria

\subsubsection{Preparation of Potato dextrose agar media and Potato dextrose broth}

To prepare potato dextrose agar $(100 \mathrm{ml})$ peeled and chopped potatoes $(20 \mathrm{~g})$ added to enough water and boiled until they become soft. Potato extract was obtained by straining the above mixture with the help of muslin cloth. To it dextrose ( $2 \mathrm{~g}$ ) and agar ( $2 \mathrm{~g}$ ) was been added and then boiled until they dissolve and made up to the volume with distilled water. The $\mathrm{pH}$ was adjusted to 5 . For potato dextrose broth $(100 \mathrm{ml})$ peeled and chopped potatoes (20 g) added to enough water and boiled until they become soft. Potato extract was obtained by straining the above mixture with the help of muslin cloth. To it dextrose $(2 \mathrm{~g})$ was been added and then boiled until dissolved and made up to the volume 
with distilled water. The pH was adjusted to 5. Further the prepared potato dextrose agar media and potato dextrose broth were subjected to sterilization in autoclave at $121^{\circ} \mathrm{C}, 15 \mathrm{lb}$ pressure for 15 minutes.

\subsubsection{Preparation of cultures}

Nutrients broth was taken and the organisms i.e. Bacillus subtillis, Proteus vulgaris, Staphylococcous aureus were subcultured from the stock culture and were incubated for $24 \mathrm{hrs}$. Potato dextrose broth was taken and the organisms i.e. Aspergillus niger, Penicillium marneffei were sub-cultured from the stock culture and were incubated for 24 hrs.

\subsubsection{Preparation of test samples}

Different concentrations of test samples were prepared by dissolving 100mg of test sample in DMSO $100 \mathrm{ml}$. Collect 0.1 $\mathrm{ml}, 0.2 \mathrm{ml}, 0.3 \mathrm{ml}, 0.4 \mathrm{ml}, 0.5 \mathrm{ml}$ separately into different volumetric flask and made up to the volume (10 ml) with DMSO to get $100 \mu \mathrm{g}, 200 \mu \mathrm{g}, 300 \mu \mathrm{g}, 400 \mu \mathrm{g}$ and $500 \mu \mathrm{g}$ per ml concentrations respectively.

\subsubsection{Antibacterial and antifungal assay}

In the present study, antimicrobial activities of the synthesized compounds were studied by the paper disc diffusion method. To evaluate the anti-bacterial activity standard drug ampicillin and anti-fungal activity standard drug ketoconazole was used. The strains of Bacillus subtillis, Proteus vulgaris, Staphylococcous aureus, Aspergillus niger and Penicillium marneffei were used from Pulla Reddy institute of pharmacy, Medak. One loop full of each strain of microorganism was transferred into a suitable agar slant by using a sterile Pasteur loop. These slants were incubated for $24 \mathrm{hrs}$ at $30{ }^{\circ} \mathrm{C}$ for bacteria and $37^{\circ} \mathrm{C}$ for fungi. Prepared plates were collected and divided into 4 equal portions. In every part of the plate one sterilized filter discs were placed which were previously dipped in different concentrations of test samples and incubated for $24 \mathrm{hrs}$. After incubation the diameter of the circular inhibition zones were measured and from these values minimum inhibitory concentrations and biological activities were calculated [37-38].

\section{Results and discussion}

Compounds $\left(\mathrm{K}_{1}, \mathrm{~K}_{2}\right.$ and $\left.\mathrm{K}_{3}\right)$ were synthesized as shown in figure 1. Compounds (K1, $\mathrm{K} 2$ and $\mathrm{K} 3$ ) were characterized by infra-red spectroscopy and ${ }^{1} \mathrm{H}$ NMR spectra. The IR and NMR spectral details are given in table 1 and table 2 respectively. The details of synthesized compounds ( $\mathrm{K}_{1}, \mathrm{~K}_{2}$ and $\left.\mathrm{K}_{3}\right)$ like molecular structure, nature of compound, yield, molecular formula and molecular weight is given are table 3.

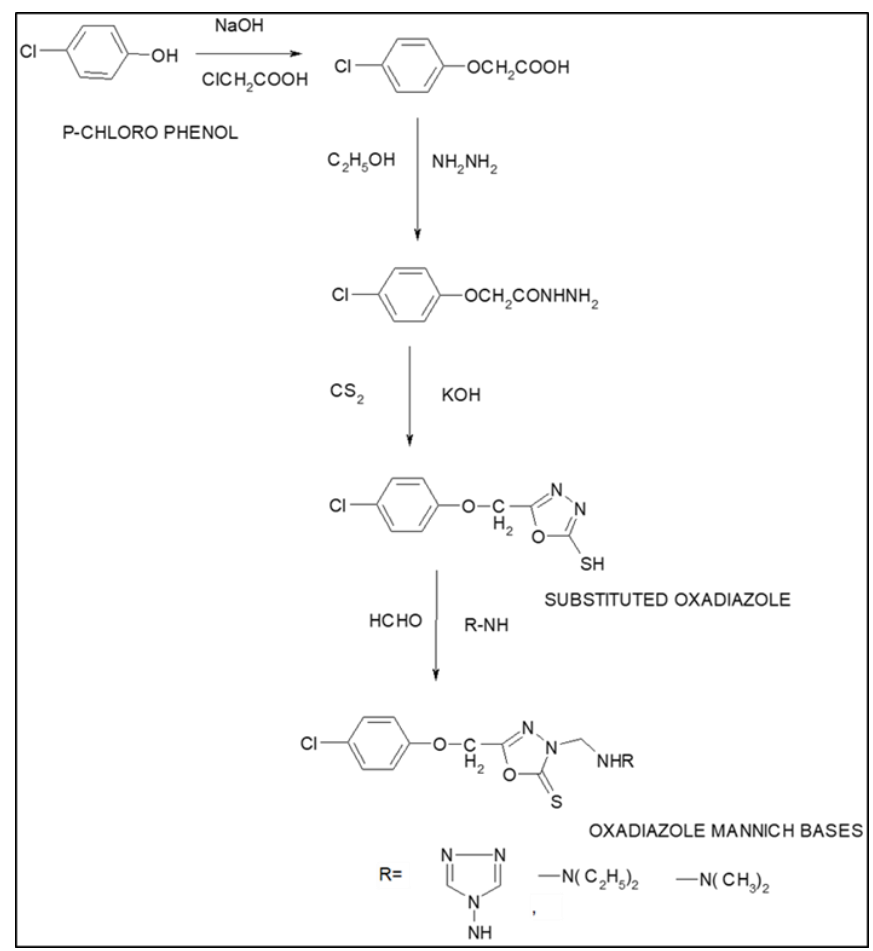

Figure 1 Scheme for synthesis of substituted oxadiazolemannich bases 
Table 1 Infra -red spectral study of the synthesized compounds

\begin{tabular}{lll}
\hline Compound & $\begin{array}{l}\text { Spectral peaks } \\
\left(\mathbf{c m}^{-1}\right)\end{array}$ & Molecular nature \\
\hline & 2918.53 & $\mathrm{C}-\mathrm{H}$ (aromatic) \\
$\mathrm{K}_{1}$ & 2849.91 & $\mathrm{C}-\mathrm{H}$ (aliphatic) \\
& 823.09 & $\mathrm{C}=\mathrm{S}$ \\
& 659.55 & $\mathrm{Cl}-\mathrm{Cl}$ \\
\hline & 2921.68 & $\mathrm{C}-\mathrm{H}$ \\
$\mathrm{K}_{2}$ & 1633.83 & $\mathrm{C}=\mathrm{O}$ \\
& 823.04 & $\mathrm{C}=\mathrm{S}$ \\
& 659.94 & $\mathrm{C}-\mathrm{Cl}$ \\
\hline & 2922.75 & $\mathrm{C}-\mathrm{H}$ \\
$\mathrm{K}_{3}$ & 822.16 & $\mathrm{C}=\mathrm{S}$ \\
& 659.71 & $\mathrm{C}-\mathrm{Cl}$ \\
\hline
\end{tabular}

Table $2{ }^{1} \mathrm{H}$ NMR Spectral data of synthesized compounds

\begin{tabular}{lll}
\hline Compound & Chemical shift value & Proton nature \\
\hline \multirow{2}{*}{$\mathrm{K}_{1}$} & $7.093-7.409$ & $4 \mathrm{Ar}-\mathrm{H}$ \\
& $5.292-5.336$ & $2 \mathrm{CH} 2$ \\
& $1.333-1.380$ & $2 \mathrm{CH} 3$ \\
\hline \multirow{2}{*}{$\mathrm{K}_{2}$} & $7.093-7.407$ & $6 \mathrm{Ar}-\mathrm{H}$ \\
\hline & $5.315-5.332$ & $2 \mathrm{CH} 2$ \\
$\mathrm{~K}_{3}$ & $7.079-7.407$ & $\mathrm{Ar}-\mathrm{H}$ \\
\hline
\end{tabular}

Table 3 Characterization of synthesized compounds

\begin{tabular}{|c|c|c|c|c|c|}
\hline Sr. No & $\begin{array}{l}\text { Molecular } \\
\text { structure }\end{array}$ & $\begin{array}{l}\text { Nature of } \\
\text { compound }\end{array}$ & $\begin{array}{l}\text { Yield } \\
(\%)\end{array}$ & $\begin{array}{l}\text { Molecular } \\
\text { formula }\end{array}$ & $\begin{array}{l}\text { Molecular } \\
\text { weight (gm) }\end{array}$ \\
\hline $\mathrm{K}_{1}$ & & White & 65 & $\mathrm{C}_{14} \mathrm{H}_{18} \mathrm{O}_{2} \mathrm{~N}_{3} \mathrm{SCl}$ & 327.5 \\
\hline $\mathrm{K}_{2}$ & & White & 54 & $\mathrm{C}_{12} \mathrm{H}_{10} \mathrm{O}_{2} \mathrm{~N}_{5} \mathrm{SCl}$ & 325.5 \\
\hline \multicolumn{6}{|l|}{$\mathrm{K}_{3}$} \\
\hline & & White & 45 & $\mathrm{C}_{18} \mathrm{H}_{12} \mathrm{O}_{4} \mathrm{~N}_{3} \mathrm{SCl}$ & 389.5 \\
\hline
\end{tabular}


Bakshi et al. / GSC Biological and Pharmaceutical Sciences 2019, 06(02), 009-020

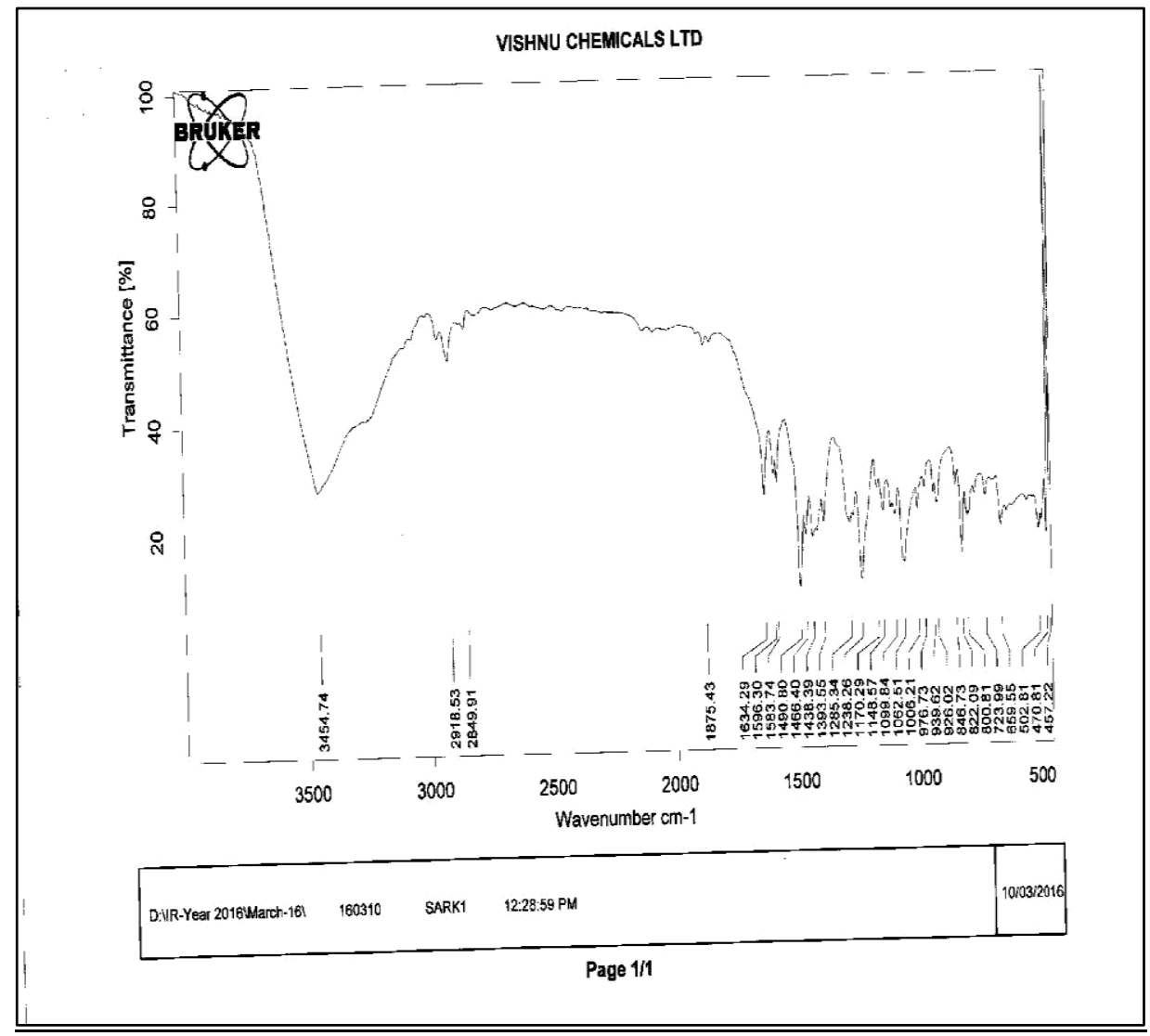

Figure 2 Infra-red spectroscopy of $\mathrm{K}_{1}$

SAR K1, 1H-DMSO-d6
240226011

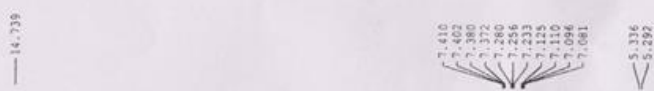

Figure $3{ }^{1} \mathrm{H}$ NMR of $\mathrm{K}_{1}$ 
Bakshi et al. / GSC Biological and Pharmaceutical Sciences 2019, 06(02), 009-020

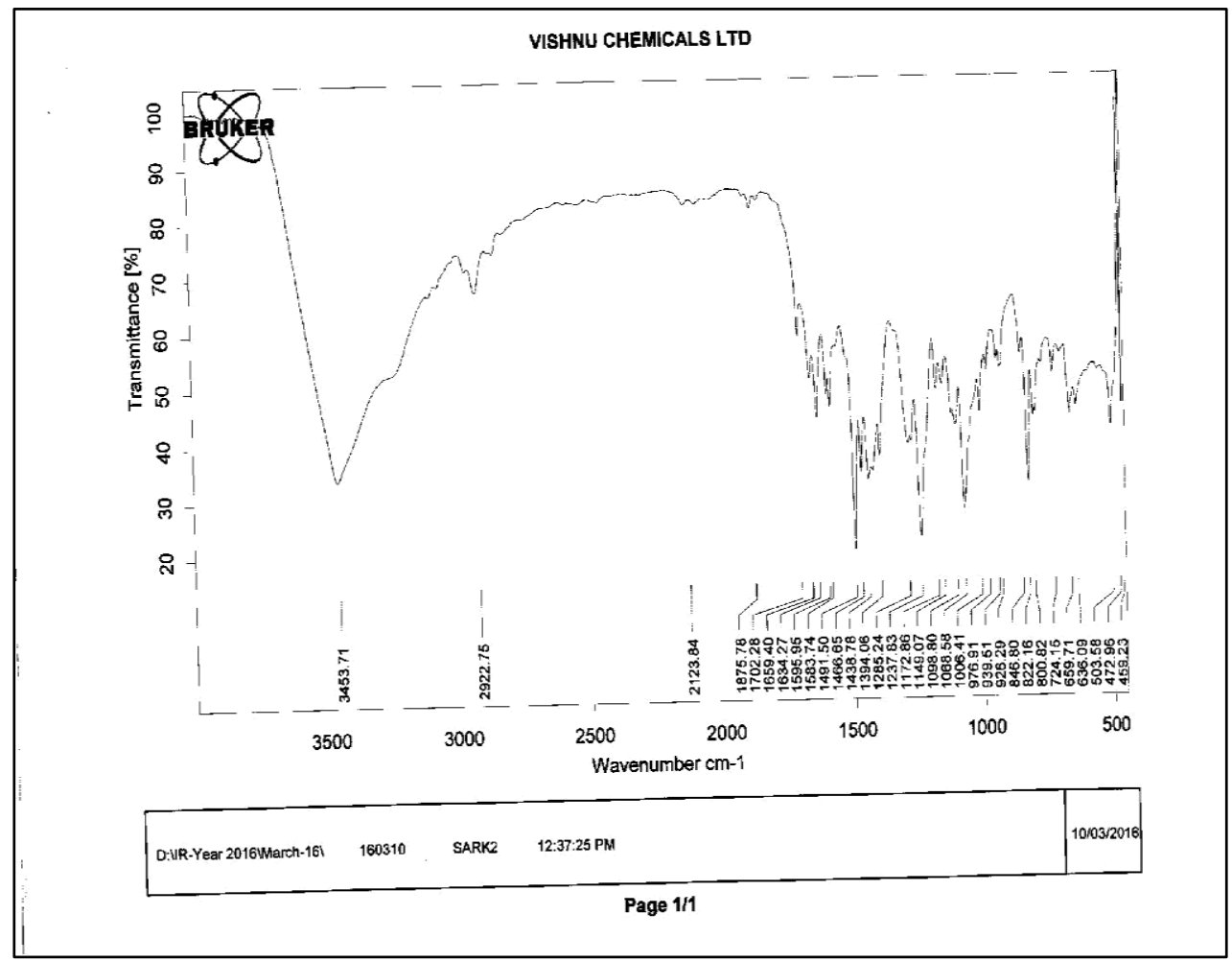

Figure 4 Infra-red spectroscopy of $\mathrm{K}_{2}$

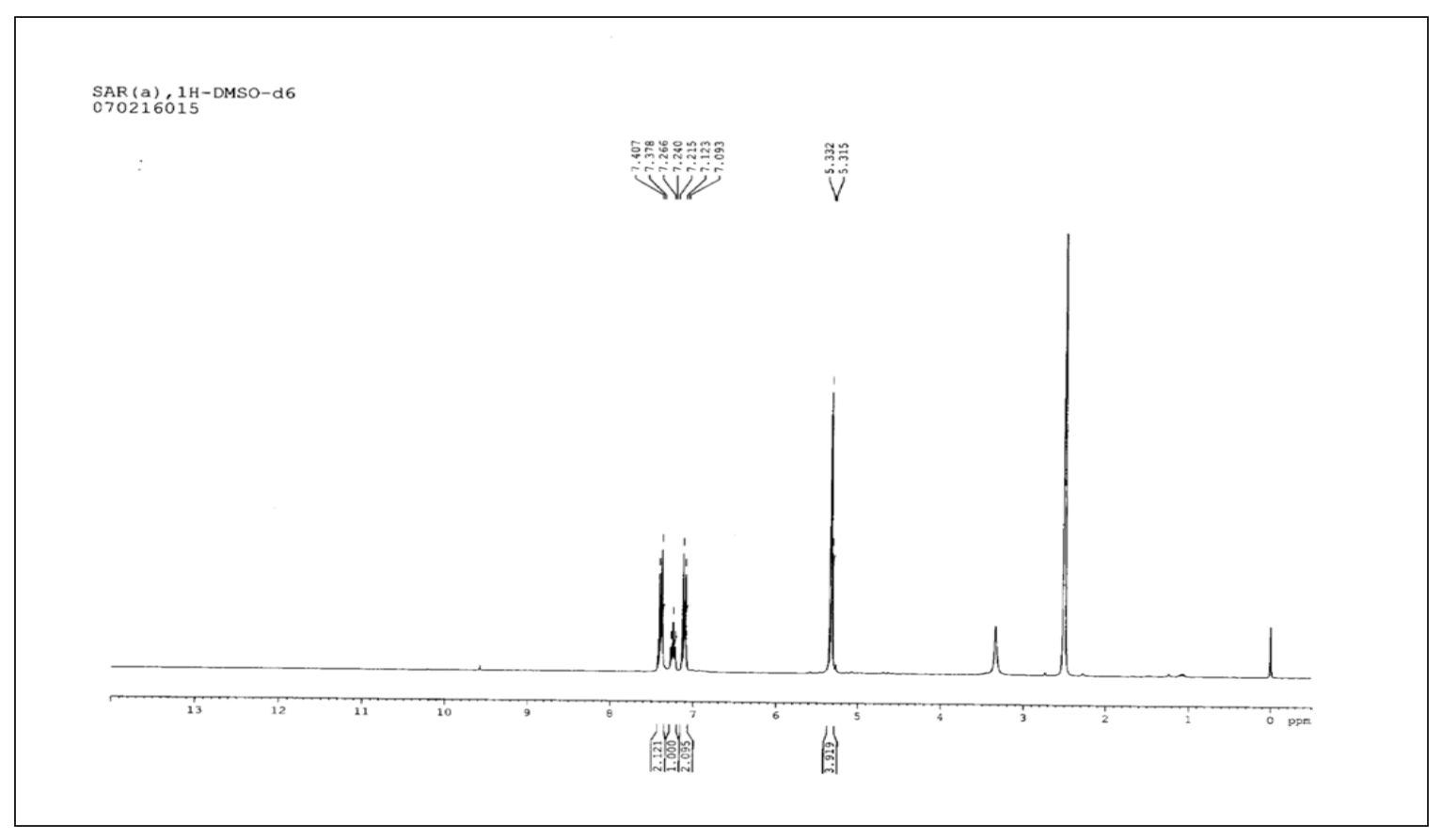

Figure $5^{1} \mathrm{H}$ NMR of K2 


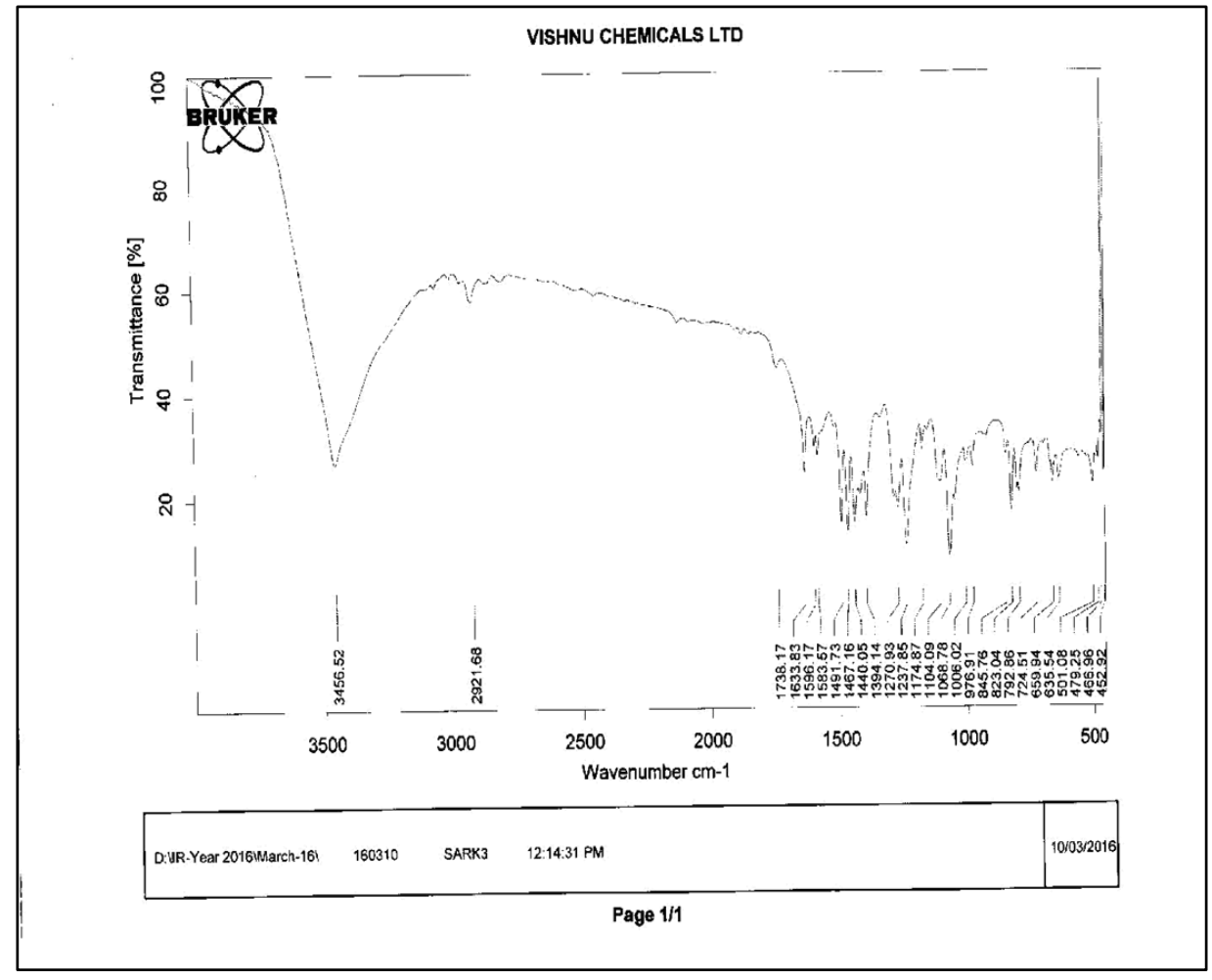

Figure 6 Infra-red spectroscopy of $\mathrm{K}_{3}$

SAR $\{K 3\}, 1 \mathrm{H}-\mathrm{OWSO}-\mathrm{d} 6$

100316007

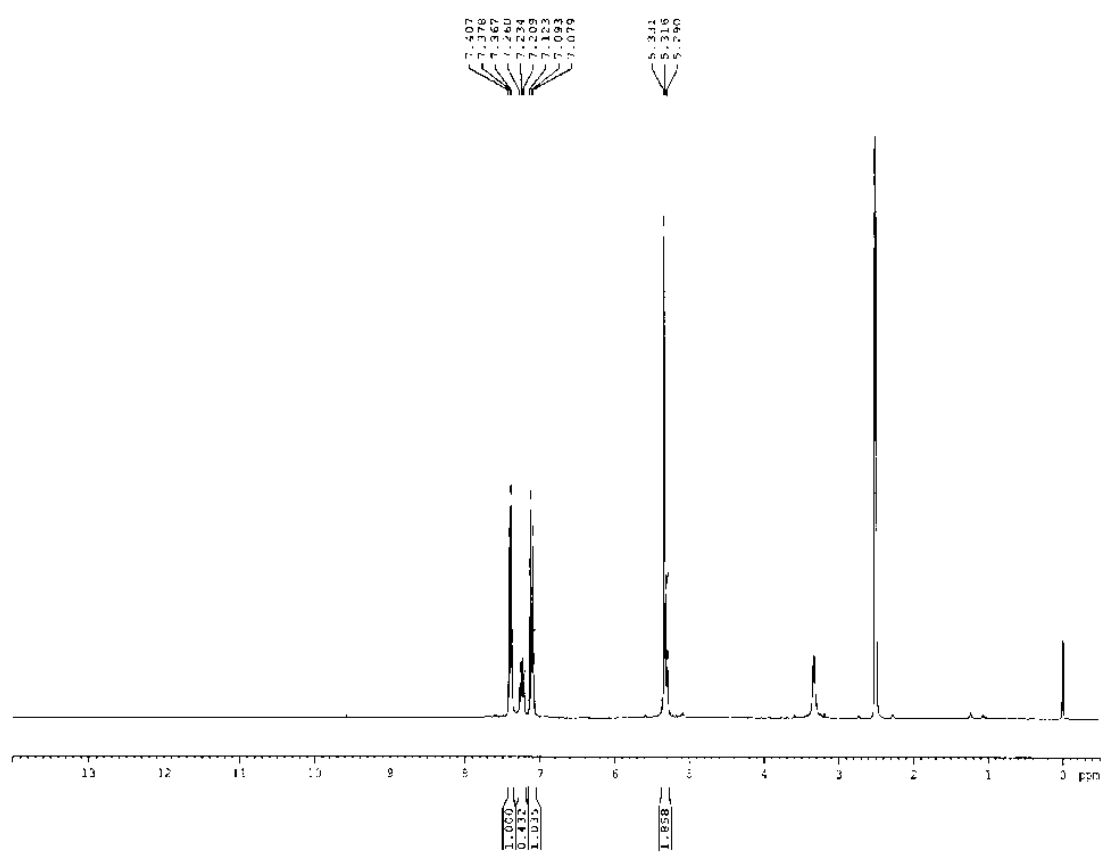

Figure $7^{1} \mathrm{H}$ NMR of $\mathrm{K}_{3}$

All the synthesized compounds of oxadiazoles in the present study showed significant activity against bacteria employed at the concentration of $100 \mu \mathrm{g} / \mathrm{ml}$ when compared with that of ampicillin as standard. The zone of inhibition of various concentrations of synthesized compounds are been summarized in the following table 4 . 
Table 4 Antibacterial activity against different bacterial strains

\begin{tabular}{|c|c|c|c|c|}
\hline \multirow[t]{2}{*}{ Compound } & \multirow{2}{*}{$\begin{array}{l}\text { Concentration } \\
(\mu \mathrm{g} / \mathrm{ml})\end{array}$} & \multicolumn{3}{|c|}{ Zone of inhibition $(\mathrm{cm})^{*}$} \\
\hline & & Bacillus subtilis & Staphylococcus aureus & Proteus vulgaris \\
\hline \multirow{5}{*}{$\mathrm{K}_{1}$} & 100 & 0.3 & 0.7 & 0.8 \\
\hline & 200 & 0.5 & 0.8 & 1.0 \\
\hline & 300 & 0.8 & 1.0 & 1.2 \\
\hline & 400 & 1.0 & 1.1 & 1.4 \\
\hline & 500 & 1.2 & 1.4 & 1.9 \\
\hline \multirow{5}{*}{$\mathrm{K}_{2}$} & 100 & 0.4 & 0.3 & 0.7 \\
\hline & 200 & 0.5 & 0.6 & 0.9 \\
\hline & 300 & 0.85 & 1.1 & 1.0 \\
\hline & 400 & 1.0 & 1.2 & 1.3 \\
\hline & 500 & 1.3 & 1.5 & 1.5 \\
\hline \multirow{5}{*}{$\mathrm{K}_{3}$} & 100 & 0.6 & 1.0 & 0.7 \\
\hline & 200 & 0.7 & 1.1 & 1.0 \\
\hline & 300 & 0.75 & 1.3 & 1.5 \\
\hline & 400 & 0.9 & 1.3 & 1.8 \\
\hline & 500 & 1.1 & 1.5 & 2.0 \\
\hline \multirow{5}{*}{ Ampicillin } & 100 & 0.5 & 0.5 & 0.9 \\
\hline & 200 & 0.9 & 0.9 & 1.2 \\
\hline & 300 & 1.3 & 1.3 & 1.5 \\
\hline & 400 & 1.5 & 1.5 & 1.8 \\
\hline & 500 & 1.6 & 1.6 & 2.0 \\
\hline
\end{tabular}

All the synthesized compounds of oxadiazole in the present study showed significant activity against the fungi employed at the concentrations of $100 \mu \mathrm{g} / \mathrm{ml}$ when compared with that of ketoconazole as standard. The zone of inhibition results was summarized below in table 5 .

Table 5 Antifungal activity against different strains

\begin{tabular}{|c|c|c|c|}
\hline \multirow[t]{2}{*}{ Compound } & \multirow{2}{*}{$\begin{array}{l}\text { Concentration } \\
(\mu \mathrm{g} / \mathrm{ml})\end{array}$} & \multicolumn{2}{|c|}{ Zone of inhibition $(\mathrm{cm})$} \\
\hline & & Aspergillus niger & Penicillium marneffei \\
\hline \multirow{5}{*}{$\mathrm{K}_{1}$} & 100 & 0.9 & 0.8 \\
\hline & 200 & 1.0 & 0.9 \\
\hline & 300 & 1.1 & 1.1 \\
\hline & 400 & 1.2 & 1.1 \\
\hline & 500 & 1.3 & 1.3 \\
\hline \multirow{5}{*}{$\mathrm{K}_{2}$} & 100 & 0.7 & 0.8 \\
\hline & 200 & 0.9 & 0.9 \\
\hline & 300 & 1.2 & 1.1 \\
\hline & 400 & 1.3 & 1.2 \\
\hline & 500 & 1.5 & 1.4 \\
\hline \multirow{5}{*}{$\mathrm{K}_{3}$} & 100 & 0.9 & 0.9 \\
\hline & 200 & 1.1 & 1.1 \\
\hline & 300 & 1.2 & 1.2 \\
\hline & 400 & 1.3 & 1.3 \\
\hline & 500 & 1.4 & 1.4 \\
\hline \multirow{5}{*}{ Ketokonazole } & 100 & 0.9 & 0.9 \\
\hline & 200 & 1.0 & 1.0 \\
\hline & 300 & 1.2 & 1.2 \\
\hline & 400 & 1.2 & 1.2 \\
\hline & 500 & 1.4 & 1.4 \\
\hline
\end{tabular}

The paper disc diffusion method is one of the methods that may be used for determining the relative effectiveness of the antimicrobial activity. The results obtained by this method depend not only on the toxicity of the antimicrobial 
agents but also on its ability to diffuse through the medium. Comparative study of minimum inhibitory concentration $\left(\mathrm{MIC}=100 \mu \mathrm{g} / \mathrm{ml}\right.$ ) of synthesized compounds against microbial strains reveals $\mathrm{K}_{3}$ compound as significant antibacterial activity against Staphylococcus aureus. $\mathrm{K}_{3}$ and $\mathrm{K}_{2}$ are more significant against fungal strains than bacterial strains used in the present investigation (figure 7).

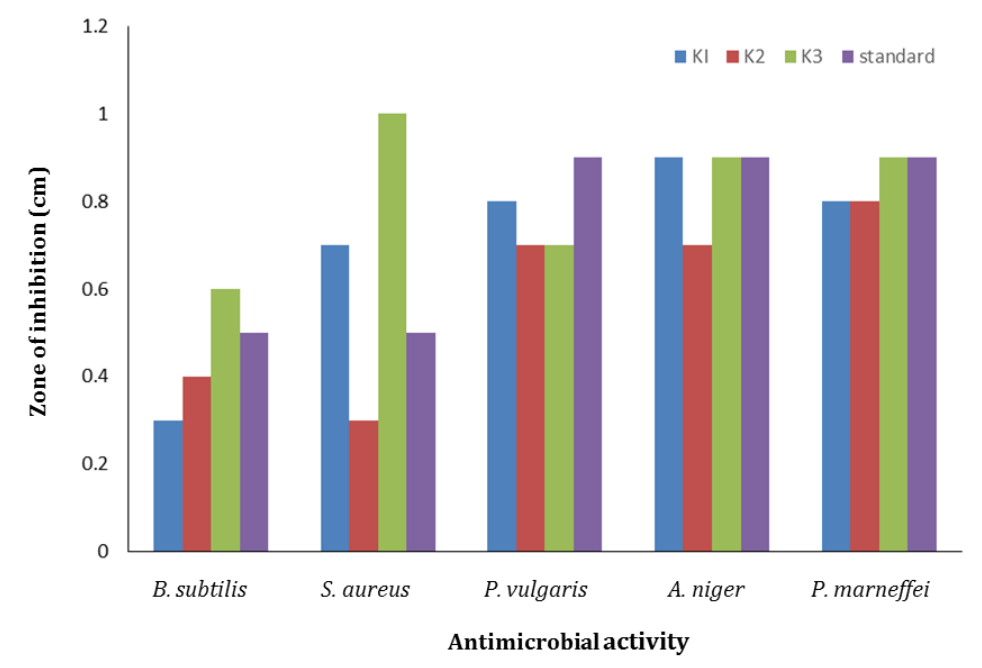

Figure 7 Comparative study of MIC $(100 \mu \mathrm{g} / \mathrm{ml})$ of synthesized compounds against microbial strains

\section{Conclusion}

In the present study, three compounds $\left(\mathrm{K}_{1}, \mathrm{~K}_{2}, \mathrm{~K}_{3}\right)$ containing oxadiazole moiety were synthesized as potential antimicrobial agents. They were evaluated for their biological activity. All the three compounds were found to possess antibacterial and antifungal activity. Compound $\mathrm{K}_{3}$ showed the significant antibacterial and antifungal activity when compared with the standards. The result of this investigation encourages us to synthesize similar other related compounds and evaluate them for a wide range of biological activity.

\section{Compliance with ethical standards}

\section{Acknowledgments}

The authors gratefully acknowledge the support provided by Sri Venkateshwara College of pharmacy, Madhapur, Hyderabad and Pulla Reddy institute of pharmacy, Medak.

\section{Disclosure of conflict of interest}

The authors declare that there are no conflicts of interest.

\section{References}

[1] Sengupta P, Mal M, Mandal S, Singh J and Maity TK. (2008). Evaluation of antibacterial and antifungal activity of some 1,3,4 oxadiazoles. Iranian Journal of Pharmacology and Therapeutics, 7(2), 165-167.

[2] Bhardwaj N, Saraf SK, Sharma P and Kumar P. (2009). Syntheses, evaluation and characterization of some 1,3,4oxadiazoles as antimicrobial agents. E-Journal of Chemistry, 6(4), 1133-1138.

[3] Kadi AA, El-Brollosy NR, Al-Deeb OA, Habib EE, Ibrahim TM and El-Emam AA. (2007). Synthesis, antimicrobial, and anti-inflammatory activities of novel 2-(1-adamantyl)-5-substituted-1,3,4-oxadiazoles and 2-(1adamantylamino)-5-substituted-1,3,4-thiadiazoles. European Journal of Medicinal Chemistry, 42(2), 235-242.

[4] Singh R and Chouhan A. (2014). Various approaches for synthesis of 1,3,4-oxadiazole derivatives and their pharmacological activity. World Journal of Pharmacy and Pharmaceutical Sciences, 3(10), 1474-1505. 
[5] Bachwani M, Sharma V and Kumar R. (2011). Biological Activities of 1,3,4-oxadiazole: A review. International Research Journal of Pharmacy, 2(12), 84-89.

[6] Ingole SP, Mohane SR and Berad BN. (2007). Synthesis and antimicrobial activity of 2-alkyl -aryl -5-(Pyrid-4-yl)1,3,4-oxadiazole. Asian Journal of Chemistry, 19, 2683-2686.

[7] Franski R. (2005). Biological activities of the compounds bearing 1,3,4-oxa (thia) diazole ring. Asian Journal of Chemistry, 17, 2063-75.

[8] Amir M, Javed SA and Kumar H. (2007). Synthesis of some 1,3,4 oxadiazole derivatives as potential antiinflammatory agents. Indian Journal of Chemistry, 46B, 1014-9.

[9] Mishra A, Singh DV and Mishra RM. (2005). Synthesis, antifungal activity of new 1,3,4 oxadiazole(3,2-b)-striazine-5-ones and their thiones analogues. Indian Journal of Heterocyclic Chemistry, 14, 289-292.

[10] Siddiqui N, Khan SA and Bhat MA. (2005). Synthesis and antibacterial activity of coumarin incorporated 1,3,4 oxadiazoles. Indian Journal of Heterocyclic Chemistry, 14, 271-2.

[11] Agarwal M, Singh V, Sharma SK, Sharma P, Ansari MY, Jadav SS and Ahsan MJ. (2016). Design and synthesis of new 2,5-disubstituted-1,3,4-oxadiazole analogues as anticancer agents. Medicinal Chemistry Research, 25(10), 2289-2303.

[12] Reddy VM, Reddy PS, Reddy PC and Ratmanc V. (1997). Cyclisation by dehydrosulfuration of 1-(2-amino benzoyl) -4-aryl-3 thiosemicarbazides. Formation of 1,3,4 benzotriazepinones, 1,3,4 thiadiazoles and 1,3,4 oxadiazoles. Indian Journal of Heterocyclic Chemistry, 7, 17-20.

[13] Singh P and Jangra PK. (2010). Oxadiazoles: A novel class of anti-convulsant agents. Pelagia Research Library, 1(3), 118-123.

[14] Bala S, Kamboj S and Kumar A. (2010). Heterocyclic 1,3,4-oxadiazole compounds with diverse biological activities: A comprehensive review. Journal of Pharmacy Research, 3(12), 2993-2997.

[15] James ND and Growcott JW. (2009). Zibotentanendothelin ETA receptor antagonist oncolytic. Drugs of the Future, 34(8), 624-633.

[16] Jones AM and Helm JM. (2009). Emerging treatments in cystic fibrosis. Drugs, 69, 1903-1910.

[17] Summa V, Petrocchi A, Bonelli F, Crescenzi B, Donghi M, Ferrara M, Fiore F, Gardelli C, Gonzalez Paz O, Hazuda DJ and Jones P. (2008). Discovery of raltegravir, a potent, selective orally bioavailable HIV-integrase inhibitor for the treatment of HIV-AIDS infection. Journal of medicinal chemistry, 51(18), 5843-5855.

[18] Brandenberger $\mathrm{H}$ and Maes RA. (Eds.). (2011). Analytical toxicology for clinical, forensic and pharmaceutical chemists (Vol. 5). Walter de Gruyter.

[19] Ducharme Y, Blouin M, Brideau C, Châteauneuf A, Gareau Y, Grimm EL, Juteau H, Laliberté S, MacKay B, Massé F and Ouellet M. (2010). The discovery of setileuton, a potent and selective 5-lipoxygenase inhibitor. ACS medicinal chemistry letters, 1(4), 170-174.

[20] Adelstein GW, Yen CH, Dajani EZ and Bianchi RG. (1976). 3, 3-Diphenyl-3-(2-alkyl-1,3,4-oxadiazol-5-yl) propylcycloalkylamines, a novel series of antidiarrheal agents. Journal of medicinal chemistry, 19(10), 12211225.

[21] Ouyang X, Piatnitski EL, Pattaropong V, Chen X, He HY, Kiselyov AS, Velankar A, Kawakami J, Labelle M, Smith II L, Lohman J. (2006). Oxadiazole derivatives as a novel class of antimitotic agents: Synthesis, inhibition of tubulin polymerization, and activity in tumor cell lines. Bioorganic \& medicinal chemistry letters, 16(5), 1191-1196.

[22] Ichiro H. (1967). Synthesis of 5-C2-(5-Initro-2-fury1)-1-(2-furyl) vinyl)-2-amino-1,3,4-0Xadia20le. NAwKagairZassi, 88, 574-575.

[23] Ogata M, Atobe H, Kushida $H$ and Yamamoto K. (1971). In vitro sensitivity of mycoplasmas isolated from various animals and sewage to antibiotics and nitrofurans. The Journal of antibiotics, 24(7), 443-451.

[24] Kadi AA, El-Brollosy NR, Al-Deeb OA, Habib EE, Ibrahim TM and El-Emam AA. (2007). Synthesis, antimicrobial, and anti-inflammatory activities of novel 2-(1-adamantyl)-5-substituted-1,3,4-oxadiazoles and 2-(1adamantylamino)-5-substituted-1,3,4-thiadiazoles. European Journal of Medicinal Chemistry, 42(2), 235-242.

[25] Mickevičius V, Vaickelioniene R and Sapijanskaite B. (2009). Synthesis of substituted 1,3,4-oxadiazole derivatives. Chemistry of Heterocyclic Compounds, 45(2), 215-218. 
[26] Bentiss F and Lagrenee M. (1999). A new synthesis of symmetrical 2,5-disubstituted 1,3,4-oxadiazoles. Journal of Heterocyclic Chemistry, 36(4), 1029-1032.

[27] Liras S, Allen MP and Segelstein BE. (2000). A mild method for the preparation of 1,3,4-oxadiazoles: triflic anhydride promoted cyclization of diacylhydrazines. Synthetic Communications, 2000, 30(3), 437-443.

[28] Gomes D, Borges CP and Pinto JC. (2001). Study of the synthesis of poly(4,4'-diphenylether-1,3,4-oxadiazole) in solutions of poly(phosphoric acid). Polymer, 42(3), 851-865.

[29] Souldozi A and Ramazani A. (2007). The reaction of (N-isocyanimino) triphenylphosphorane with benzoic acid derivatives: a novel synthesis of 2-aryl-1,3,4-oxadiazole derivatives. Tetrahedron Letters, 48(9), 1549-1551.

[30] Ramazani A, Abdian B, Nasrabadi FZ and Rouhani M. (2013). The reaction of Nisocyaniminotriphenylphosphorane with biacetyl in the presence of $(E)$-cinnamic acids: synthesis of fully substituted 1,3,4-oxadiazole derivatives via intramolecular aza -wittig reactions of in situ generated iminophosphoranes. Phosphorus, Sulfur and Silicon and the Related Elements, 188(5), 642-648.

[31] Ramazani A, ZeinaliaNasrabadi F and Ahmadi Y. (2011). One-pot, four-component synthesis of fully substituted 1,3,4-oxadiazole derivatives from (Isocyanoimino) triphenylphosphorane, a primary amine, an aromatic carboxylic acid, and chloroacetone. Helvetica ChimicaActa, 94(6), 1024-1029.

[32] Ramazani A and Souldozi A. (2008). Iminophosphorane-mediated one-pot synthesis of 1,3,4-oxadiazole derivatives. Arkivoc, 16, 235-242.

[33] Pitasse-Santos P, Sueth-Santiago V and Lima ME. (2018). 1,2,4- and 1,3,4-Oxadiazoles as scaffolds in the development of antiparasitic agents. Journal of the Brazilian Chemical Society, 29(3), 435-456.

[34] de Oliveira CS, Lira B, Barbosa-Filho JM, Lorenzo JG and de Athayde-Filho PF. (2012). Synthetic approaches and pharmacological activity of 1, 3, 4-oxadiazoles: a review of the literature from 2000-2012. Molecules, 17(9), 10192-10231.

[35] Zheng X, Li Z, Wang Y, Chen W, Huang Q, Liu C and Song G. (2003). Syntheses and insecticidal activities of novel 2,5-disubstituted 1,3,4-oxadiazoles. Journal of Fluorine Chemistry, 123(2), 163-169.

[36] Kumar R, Yar MS, Rai AK and Chaturvedi S. (2013). Synthesis and biological evaluation of some novel 1,3,4oxadiazoles derived from bi phenyl 4- carboxylic acid. Der Pharmacia Lettre, 5(1), 366-370.

[37] Maslat AO, Abussaud M, Tashtoush H and Al-Talib M. (2002). Synthesis, antibacterial, antifungal and genotoxic activity of bis-1,3,4-oxadiazole derivatives. Polish Journal of Pharmacology, 2002, 54, 55-59.

[38] Grewal AS and Redhu S. (2014). Synthesis, antibacterial and antifungal activity of 2, 5-disubstituted-1, 3, 4oxadiazole derivatives. Synthesis, 6(7), 2015-2021.

\section{How to cite this article}

Bakshi A, Kammari S, Awasthi A, Bhutada S, PolaS and Mantripragada BR. (2019). Synthesis and evaluation of some novel heterocyclic compounds containing an oxadiazole moiety. GSC Biological and Pharmaceutical Sciences, 6(2), 0920. 